\title{
Genetic studies on yield and some related characters in two bread wheat crosses using five population model
}

\author{
Mohamed M. Mohamed ${ }^{1}$, Mohamed A. M. Eid and Sherif R. M. El-Areed ${ }^{3 *}$ \\ ${ }^{1}$ Wheat Research Department, Field Crops Research Institute, ARC, Egypt, ${ }^{2}$ Agronomy Dep., Faculty of \\ Agriculture, Fayoum University, Fayoum 63514, ${ }^{3}$ Agronomy Dep., Faculty of Agriculture, Beni-Suef \\ University, Egypt \\ *Corresponding Author: sharif.rajab@agr.bsu.edu.eg
}

Received on: 18-5-2021
Accepted on: 29-5-2021

\begin{abstract}
This study were implemented within four growing seasons from 2017/2018 to 2020/2021. The five populations $\left(\mathrm{P}_{1}, \mathrm{P}_{2}, \mathrm{~F}_{1}\right.$, $F_{2}$ and $F_{3}$ ) of two crosses of bread wheat (Misr 3 x Shandaweel-1 and Giza 168 x Sakha 94) were evaluated in two locations during 2020/2021 growing season, at West West El-Minia and Sids Agricultural Research Station, Agricultural Research Center, Egypt, In order to determine the mode of gene action and the inheritance pattern of plant height, no. of spikes plant ${ }^{-}$ ${ }^{1}$, no. of kernels spike ${ }^{-1}, 100$-kernel weight and grain yield plant ${ }^{-1}$. The t-test showed significant differences among parental genotypes of each cross for all studied characters. The mean effects $(\mathrm{m})$ were highly significant for all characters under the study in the two crosses and locations, indicating the ability to enhance the performance of these characters by pedigree selection. Scaling test revealed the presence of nonallelic interactions (epistasis) in the most studied characters. Dominance gene effects were generally greater than additive ones in most characters. Gene effects varied among characters, whereas the dominance and duplicate dominance beside additive gene effects were found to play important role in the inheritance of most studied characters. The desired significant and highly significant positive heterotic effects to mid-parents for two crosses were detected in the two locations. Broad sense heritability estimates displayed moderate values in most characters. The highest expected genetic gain was found to be correlated with high heritability in narrow sense estimated in all studied characters.
\end{abstract}

KEYWORDS : Gene action, Genetic advance, Heritability, Heterosis, Inbreeding depression, Triticum aestivum $\mathrm{L}$,

\section{INTRODUCTION}

Wheat (Triticum aestivum, L.) crop is considered one of the essential strategic cereal crops not only in Egypt but also all over the world. In addition, wheat is the world's most important food crop in terms of tons of grain produced each year. Wheat trade represents a significant component of the trade balance of national economy. Wheat is utilized and processed for many products, reflecting its importance for large quantities produced by people of diverse cultures and social groups (Faridi and Faubion, 1995).

Breeding procedures for genetic improvement of any crop is largely dependent on the knowledge of type and relative amount of genetic component and the presence of non-allelic interaction for different characters in the plant materials under investigations. Generations analysis is a useful technique in plant breeding for estimating main gene effects (additive and dominance) and their di genic (additive $\times$ additive and dominance $\times$ dominance) interactions responsible for inheritance of quantitative traits. It helps the breeders to understand the performance of the parents used in crosses (Zaazaa et al 2012). Polygenic systems have properties which are basic to our understanding of the genetical structure of populations, their variation and their responses to selection (Mather 1973). Grain yield attributes in wheat may have more heritable than yield itself (Fethi and Mohamed 2010). High heritability estimates, coupling with other parameters can be used in predicting genetic gain follows by selection for these characters. Selection of different wheat genotypes under environmental stress conditions is one of the main missions of crop breeders for exploiting the genetic variations to improve the stress tolerant wheat cultivars (Gebrel et 
al., 2014; Khan and Mohammad, 2016; Al-Naggar et al., 2017).

The objective of this study is determine the genetic control of yield and yield component traits by genetic analysis among generation means under clay and sandy soil conditions in wheat. To explain the possibility of development genotypes among different generations, showing the best promising ones. Also, these data can help to improve breeding strategies for grain yield.

\section{MATERIALS AND METHODS}

This study was carried out during four successive seasons, in 2017/2018, 2018/2019, 2019/2020 and 2020/2021, at West West El-Minia (sandy soil) and Sids Agricultural Research Station (clay soil), Agricultural Research Center, Egypt. Four bread wheat genotypes (Triticum aestivum L.) were used as parental lines. The commercial names and pedigree are presented as follows:-

Table 1. The commercial names and pedigree of the four parents of bread wheat genotypes.

\begin{tabular}{|c|c|c|}
\hline Parent & Name & Cross Name and selection history \\
\hline D1 & Mian 2 & Rohf $07 * 2 /$ Kiriti \\
\hline P1 & NHIST 3 & CGSS 05 B00123T-099T 0PY-099M-099NJ-6WGY-0B-0BGY-0GZ \\
\hline P2 & & SITE//MO/4/NAC/TH.AC//3*PVN/3/MIRLQ/BUC. \\
\hline $\mathrm{P} 2$ & Snanaween I & CMSS93B 00567 S-72Y-010M-010Y-010M-OHTY-OSH \\
\hline P3 & Giza 168 & $\begin{array}{l}\text { MRL / BUC // SERI } \\
\text { CM93046-8M-0Y-0M-2Y-0B-0GZ }\end{array}$ \\
\hline P4 & Sakha 94 & $\begin{array}{l}\text { Opata/Rayon//Kauz } \\
\text { CMBW90Y3180-0TOPM-3Y-010M 010M-010Y-10M-015Y-0Y }\end{array}$ \\
\hline
\end{tabular}

\subsection{Experimental procedures}

In 2017/2018 season two $\mathrm{F}_{1}$ 's/hybrids were performed, i.e. Hybrid 1: Misr 3 x Shandaweel-1 and Hybrid 2: Giza $168 \times$ Sakha 94 . Obtained grains from the two hybrids of $F_{1} s^{\prime}$ and $F_{2}$ 's were raised to produce $F_{2}$ 's and $F_{3}$ 's in 2018/19 and 2019/20 seasons, respectively. Parents, $F_{1}, F_{2}$ and $F_{3}$ generations of the two hybrids were evaluated in a randomized complete block design with three replications in 2020/21 season under clay and sandy soil conditions at Sids and West West El-Minia, respectively.

Each experimental plot consisted of 15 rows (one row for each of $\mathrm{P}_{1}, \mathrm{P}_{2}$ and $\mathrm{F}_{1}$ 's, six rows for each of $F_{2}$ 's and $F_{3}$ 's) besides two border rows were planted to avoid the border effects. The rows were $4 \mathrm{~m}$ long, $25 \mathrm{~cm}$ apart and $10 \mathrm{~cm}$ among plants within row. All cultural practices were conducted during the growing season according to the recommendations. Data on 30 individual randomly selected plants from each parent and $F_{1}$ 's generation, 200 plants from $F_{2}$ 's and 230 plants from $\mathrm{F}_{3}$ 's population were recorded to calculate the studied traits (Plant height, number of spikes plant ${ }^{-}$ ${ }^{1}$, number of kernels spike ${ }^{-1}, 100$-kernel weight and grain yield plant $^{-1}$ ) for all populations of the two crosses under clay and sandy field conditions.

Table 2. locations characteristics and their agro-climatic conditions

\begin{tabular}{|c|c|c|c|c|c|c|c|c|}
\hline \multirow[t]{2}{*}{ Location } & \multirow{2}{*}{$\begin{array}{l}\text { Growing } \\
\text { season }\end{array}$} & \multirow[t]{2}{*}{ Latitude } & \multirow[t]{2}{*}{ Longitude } & \multirow[t]{2}{*}{ Soil type } & \multirow[t]{2}{*}{ Altitude } & \multicolumn{3}{|c|}{ Temperature $\left(\mathrm{c}^{\mathrm{o}}\right)$} \\
\hline & & & & & & Min. & Max. & Ave. \\
\hline \multirow[t]{2}{*}{ Sids } & \multirow{2}{*}{$\begin{array}{l}2018-2019 \\
2019-2020\end{array}$} & \multirow[t]{2}{*}{$28^{\circ} 54^{\prime} \mathrm{N}$} & \multirow[t]{2}{*}{$30^{\circ} 56^{\prime} \mathrm{E}$} & \multirow[t]{2}{*}{ Clay } & \multirow[t]{2}{*}{31} & 10.65 & 25.14 & 17.36 \\
\hline & & & & & & 10.72 & 25.11 & 17.34 \\
\hline \multirow{2}{*}{$\begin{array}{l}\text { West West } \\
\text { El Mynia }\end{array}$} & \multirow{2}{*}{$\begin{array}{l}2018-2019 \\
2019-2020\end{array}$} & \multirow[t]{2}{*}{$28^{\circ} 8^{\prime} \mathrm{N}$} & \multirow[t]{2}{*}{$30^{\circ} 32^{\prime} \mathrm{E}$} & \multirow[t]{2}{*}{ Sandy } & \multirow[t]{2}{*}{101} & 10.87 & 24.49 & 16.89 \\
\hline & & & & & & 10.27 & 24.36 & 16.78 \\
\hline
\end{tabular}

\subsection{Biometrical analysis}

The collected data were subjected to analysis of variance for the five population means to perform differences among generations. The scaling test variance, standard error and ' $t$ ' test were calculated to detect the interactions or to fit in simple additivedominance model. The considered-five parameters included mean effects (m), additive (d) and dominance (h) gene effects and types of epistasis ( $\mathrm{I}=$ additive $\mathrm{x}$ additive and $1=$ dominance $\mathrm{x}$ dominance). The variance and standard errors for each of these parameters ( $\mathrm{m}, \mathrm{d}, \mathrm{h}, \mathrm{i}$ and $\mathrm{l})$ were calculated and the significance of each one was tested using t-test. The type of epistasis was determined only when dominance $[\mathrm{h}]$ and dominance $\mathrm{x}$ dominance [1] effects were significant, recording complementary epistasis in the same effects sign and duplicate epistasis in 
different signs (Mather and Jinks 1982). Both broad and narrow-sense heritability, potence ratio, heterosis relative to mid and best parent and inbreeding depression (\%) were calculated according to Mather and Jinks (1982). Genetic advance as percentage of the $\mathrm{F}_{2}$ mean were estimated as reported by Allard (1999). The t-test was used to determine the significance of these parameters where the standard error (SE) was calculated. On the other hand, the expected and actual genetic advance $(\Delta \mathrm{g})$ was computed according to Johanson et al. (1955). Similarly, the genetic gain percentage of the $\mathrm{F}_{2}$ and $\mathrm{F}_{3}$ mean performance $(\Delta \mathrm{g} \%)$ was estimated using the method of Miller et al. (1958).

\section{RESULTS AND DISCUSSION}

\subsection{Generation Mean}

The choice of the parents to be crossed in breeding programs are the most important problem facing the breeder .If the parents are precisely selected, the desired characteristics will be found in the segregated generations (Mahrous,1998). The parental differences in response to their genetic background were found to be significant in most characters under investigation.

Results in (Table 3 and 4) present mean performance and variance for the studied characters using the five populations $\left(\mathrm{P}_{1}, \mathrm{P}_{2}, \mathrm{~F}_{1}, \mathrm{~F}_{2}\right.$ and $\left.\mathrm{F}_{3}\right)$ of the two bread wheat populations under clay and sandy soil conditions for the investigated characters. The t-test performed between parents of each cross (Table 3 and 4) showed significance in all characters in the two crosses under the study.

\subsubsection{First cross}

Results in Table (3) showed that, among the investigated parents, genotype Misr 3 revealed the best values for all characters in clay soil location except number of kernels spike ${ }^{-1}$, recorded the highest mean

Table 3. Mean performance and variances of five populations for the tested characters in the first bread wheat cross.

\begin{tabular}{|c|c|c|c|c|c|c|c|c|}
\hline \multirow{2}{*}{$\frac{\text { Trait }}{\text { Hybrid } 1}$} & \multirow{2}{*}{ Location } & \multirow{2}{*}{ Statis. } & \multirow{2}{*}{$\frac{\mathrm{P}_{1}}{\text { Misr } 3}$} & \multirow{2}{*}{$\frac{\mathrm{P}_{2}}{\text { Shandaweel 1 }}$} & \multicolumn{3}{|c|}{ Filial generations } & \multirow{2}{*}{ t.test } \\
\hline & & & & & $\mathrm{F}_{1}$ & $\mathrm{~F}_{2}$ & $\mathrm{~F}_{3}$ & \\
\hline \multirow{4}{*}{ 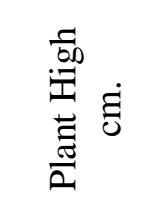 } & \multirow{2}{*}{1} & $\bar{x}$ & 108.50 & 93.83 & 115.17 & 115.74 & 114.15 & \multirow{2}{*}{$*$} \\
\hline & & $S^{2}$ & 35.25 & 21.14 & 20.81 & 444.24 & 276.28 & \\
\hline & \multirow{2}{*}{2} & $\bar{x}$ & 98.67 & 89.83 & 109.50 & 109.02 & 104.50 & \multirow[t]{2}{*}{$*$} \\
\hline & & $S^{2}$ & 38.22 & 27.47 & 27.25 & 387.20 & 228.50 & \\
\hline \multirow{4}{*}{ 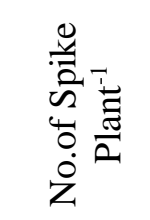 } & \multirow{2}{*}{1} & $\bar{x}$ & 26.13 & 22.57 & 28.57 & 20.79 & 19.71 & \multirow[t]{2}{*}{$*$} \\
\hline & & $S^{2}$ & 26.57 & 21.36 & 31.53 & 50.27 & 39.62 & \\
\hline & \multirow{2}{*}{2} & $\bar{x}$ & 15.94 & 19.88 & 22.79 & 15.24 & 17.65 & \multirow[t]{2}{*}{$*$} \\
\hline & & $S^{2}$ & 11.68 & 12.08 & 16.44 & 31.01 & 26.23 & \\
\hline \multirow{4}{*}{ 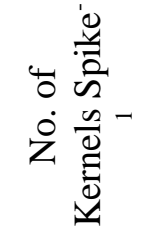 } & \multirow{2}{*}{1} & $\bar{x}$ & 60.70 & 66.28 & 69.64 & 62.33 & 59.72 & \multirow[t]{2}{*}{$*$} \\
\hline & & $S^{2}$ & 85.67 & 66.15 & 98.42 & 317.56 & 263.88 & \\
\hline & \multirow{2}{*}{2} & $\bar{x}$ & 59.95 & 67.19 & 69.13 & 61.62 & 58.38 & \multirow[t]{2}{*}{$*$} \\
\hline & & $S^{2}$ & 81.25 & 65.96 & 92.33 & 296.17 & 253.70 & \\
\hline \multirow{4}{*}{ 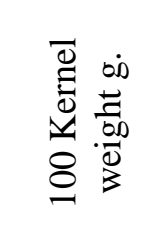 } & \multirow{2}{*}{1} & $\bar{x}$ & 5.352 & 4.984 & 5.568 & 4.569 & 4.518 & \multirow[t]{2}{*}{$*$} \\
\hline & & $S^{2}$ & 0.322 & 0.178 & 0.403 & 0.801 & 0.703 & \\
\hline & \multirow{2}{*}{2} & $\bar{x}$ & 4.371 & 4.973 & 5.143 & 3.932 & 3.842 & \multirow[t]{2}{*}{$*$} \\
\hline & & $S^{2}$ & 0.130 & 0.289 & 0.403 & 0.618 & 0.547 & \\
\hline \multirow{4}{*}{ 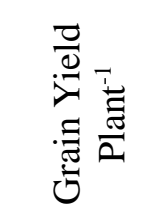 } & \multirow{2}{*}{1} & $\bar{x}$ & 49.82 & 45.47 & 48.87 & 24.71 & 25.27 & \multirow[t]{2}{*}{$*$} \\
\hline & & $S^{2}$ & 25.82 & 38.36 & 34.71 & 180.64 & 138.58 & \\
\hline & \multirow{2}{*}{2} & $\bar{x}$ & 34.74 & 38.81 & 42.41 & 20.33 & 19.59 & \multirow[t]{2}{*}{$*$} \\
\hline & & $S^{2}$ & 37.76 & 36.17 & 26.10 & 166.72 & 129.60 & \\
\hline
\end{tabular}

*, ** Significant and highly significant at 0.05 and 0.01 respectively. 
values for plant height $(108.50,98.67 \mathrm{~cm}$ in two location ), number of spikes plant ${ }^{-1}$ (26.13 spike), 100kernel weight $(5.352 \mathrm{~g})$ and grain yield plant $^{-1}$ (49.82g). However, the second parent Shandaweel-1 had the maximum number for all characters in sandy soil location except plant height and 100-kernel weight in the two locations, recorded the highest mean values for number of kernels spike $^{-1}(66.28,67.19$ kernels in two type of soil) and gave the highest mean values for number of spikes plant ${ }^{-1}$ (20.57 spike) and grain yield plant ${ }^{-1}(38.81 \mathrm{~g})$ in sandy soil.

In filial generations, $F_{1}$ 's mean presented best performance for all characters under study in the two locations except plant height in Sids location. In $\mathrm{F}_{2}$ 's, results revealed best values for plant height in clay soil.

\subsubsection{Second cross}

Table (4) showed that among the investigated parents, genotype Giza 168 revealed the best values for all characters under study in the two locations except number of spikes plant ${ }^{-1}$, recorded the highest mean values for plant height $(111.83$ and $101.50 \mathrm{~cm})$, number of kernels spike ${ }^{-1}$ (66.o3 and 63.53 kernels), 100-kernel weight (4.926 and $4.413 \mathrm{~g}$ ) and grain yield plant $^{-1}$ (44.24 and $34.12 \mathrm{~g}$ ) in the two locations, respectively. However, parent Sakha 94 had the maximum values for number of spikes plant ${ }^{-1}(21.38$ and 18.29 spike) in the two locations respectively.

In filial generations, $F_{1}$ 's mean presented best performance for all characters under study in the two locations.

Table 4. Mean performance and variances of five populations for the tested characters in the second bread wheat cross.

\begin{tabular}{|c|c|c|c|c|c|c|c|c|}
\hline \multirow{2}{*}{$\begin{array}{c}\text { Trait } \\
\text { Hybrid } 2\end{array}$} & \multirow{2}{*}{ Location } & \multirow{2}{*}{ Statis. } & $\mathrm{P}_{1}$ & $\mathrm{P}_{2}$ & \multicolumn{3}{|c|}{ Filial generations } & \multirow{2}{*}{ t.test } \\
\hline & & & Giza 168 & Sakha 94 & $\mathrm{~F}_{1}$ & $\mathrm{~F}_{2}$ & $\mathrm{~F}_{3}$ & \\
\hline \multirow{4}{*}{ 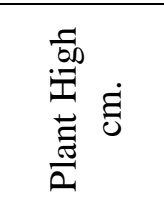 } & \multirow{2}{*}{1} & $\overline{\bar{x}}$ & 111.83 & 103.83 & 117.33 & 110.76 & 109.65 & \multirow{2}{*}{$*$} \\
\hline & & $S^{2}$ & 19.14 & 14.47 & 17.89 & 260.83 & 225.13 & \\
\hline & \multirow{2}{*}{2} & $\bar{x}$ & 101.50 & 91.17 & 105.50 & 99.76 & 103.83 & \multirow{2}{*}{$*$} \\
\hline & & $S^{2}$ & 23.58 & 27.81 & 27.25 & 235.70 & 173.24 & \\
\hline \multirow{4}{*}{ 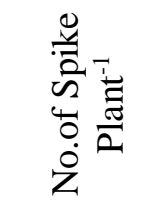 } & \multirow{2}{*}{1} & $\bar{x}$ & 17.70 & 21.38 & 21.60 & 12.67 & 13.48 & \multirow{2}{*}{$*$} \\
\hline & & $S^{2}$ & 17.24 & 17.99 & 26.08 & 57.56 & 39.95 & \\
\hline & \multirow{2}{*}{2} & $\bar{x}$ & 13.70 & 18.29 & 19.95 & 11.42 & 10.59 & \multirow{2}{*}{$*$} \\
\hline & & $S^{2}$ & 17.24 & 9.84 & 25.22 & 46.99 & 40.25 & \\
\hline \multirow{4}{*}{ 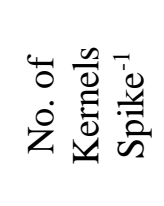 } & \multirow{2}{*}{1} & $\bar{x}$ & 62.73 & 58.29 & 69.81 & 57.44 & 64.29 & \multirow{2}{*}{$*$} \\
\hline & & $S^{2}$ & 37.80 & 47.13 & 44.00 & 178.72 & 140.99 & \\
\hline & \multirow{2}{*}{2} & $\bar{x}$ & 63.53 & 56.16 & 68.63 & 57.15 & 60.29 & \multirow{2}{*}{$*$} \\
\hline & & $S^{2}$ & 73.19 & 57.92 & 61.98 & 161.42 & 140.98 & \\
\hline \multirow{4}{*}{ 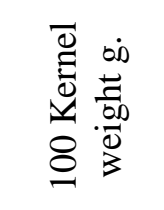 } & \multirow{2}{*}{1} & $\bar{x}$ & 4.926 & 4.572 & 5.029 & 4.432 & 4.440 & \multirow{2}{*}{$*$} \\
\hline & & $S^{2}$ & 0.255 & 0.265 & 0.341 & 0.755 & 0.623 & \\
\hline & \multirow{2}{*}{2} & $\bar{x}$ & 4.413 & 3.947 & 4.619 & 3.969 & 3.996 & \multirow{2}{*}{$*$} \\
\hline & & $S^{2}$ & 0.255 & 0.265 & 0.341 & 0.552 & 0.471 & \\
\hline \multirow{4}{*}{ 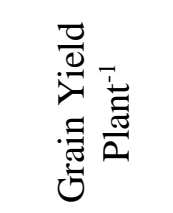 } & \multirow{2}{*}{1} & $\bar{x}$ & 44.24 & 36.15 & 54.58 & 28.07 & 27.35 & \multirow{2}{*}{$*$} \\
\hline & & $S^{2}$ & 44.47 & 65.31 & 79.80 & 179.33 & 135.80 & \\
\hline & \multirow{2}{*}{2} & $\bar{x}$ & 34.12 & 25.64 & 39.27 & 20.61 & 19.24 & \multirow{2}{*}{$*$} \\
\hline & & $S^{2}$ & 44.47 & 50.74 & 61.92 & 163.08 & 117.63 & \\
\hline
\end{tabular}

$*, * *$ Significant and highly significant at 0.05 and 0.01 respectively.

\subsection{Scaling test}

Testing for non- allelic interaction (C and D) together with the five parameters model and type of epistasis are given in Table (5). The results revealed the presence of non-allelic interaction for all the studied characters in the two studied crosses, except plant height in the second cross under clay soil. It is worthy to mention that at least one of the $\mathrm{C}$ and $\mathrm{D}$ tests was significant for the previous characters, indicating the adequacy of the five parameter model to 
Mohamed. M. Mohamed et al., 2021

Table 5. Parameters of scaling test and gene effects relating to studied characters in the two bread wheat crosses under clay and sandy soil.

\begin{tabular}{|c|c|c|c|c|c|c|c|c|c|c|c|}
\hline \multirow{2}{*}{ Trait } & \multirow{2}{*}{ Cross } & \multirow{2}{*}{ Location } & \multicolumn{2}{|c|}{ Scaling test } & \multicolumn{5}{|c|}{ Gene action } & \multirow{2}{*}{ E1 } & \multirow{2}{*}{ E2 } \\
\hline & & & $\mathrm{C}$ & $\mathrm{D}$ & $\mathrm{m}$ & d & $\mathrm{h}$ & $\mathrm{i}$ & $\mathrm{L}$ & & \\
\hline \multirow{4}{*}{ 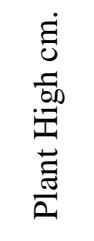 } & \multirow{2}{*}{1} & Clay & $30.29 * *$ & $22.79 * *$ & $115.7 * *$ & $7.33 * *$ & 3.86 & 4.52 & -10 & $7.57 * *$ & $11.96 * *$ \\
\hline & & Sandy & $28.59 * *$ & $11.46^{*}$ & $109.0 * *$ & $4.42^{* *}$ & $12.38 * *$ & 5.96 & $-22.84 *$ & $7.15 * *$ & $5.25 *$ \\
\hline & \multirow{2}{*}{2} & Clay & -7.29 & 1.41 & $110.8 * *$ & $4 * *$ & $7.34 *$ & --- & --- & -1.82 & $-5.87 *$ \\
\hline & & Sandy & -4.62 & $23.11 * *$ & $99.76 * *$ & $5.17 * *$ & $-7.01 *$ & -5.84 & $36.98 * *$ & -1.16 & $5.82 * *$ \\
\hline \multirow{4}{*}{ 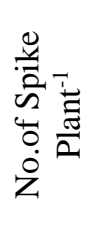 } & \multirow{2}{*}{1} & Clay & $-22.69 * *$ & $-11.45^{* *}$ & $20.79 * *$ & $1.78^{* *}$ & $8.07 * *$ & $7.42 * *$ & $14.99 * *$ & $-5.67 * *$ & $-13.50 * *$ \\
\hline & & Sandy & $-20.45^{* *}$ & 4.31 & $15.24 * *$ & $-1.97 * *$ & -1.40 & $-10.2 * *$ & $33.03 * *$ & $-5.11 * *$ & $-5.39 * *$ \\
\hline & \multirow{2}{*}{2} & Clay & $-31.59 * *$ & $-10.49 * *$ & $12.67 * *$ & $-1.84 * *$ & $3.79 *$ & -1.95 & $28.13 * *$ & $-7.89 * *$ & $-14.17 * *$ \\
\hline & & Sandy & $-26.19 * *$ & $-12.48 * *$ & $11.42 * *$ & $-2.29 * *$ & $7.91 * *$ & -0.63 & $18.28 * *$ & $-6.55^{* *}$ & $-14.77 * *$ \\
\hline \multirow{4}{*}{ 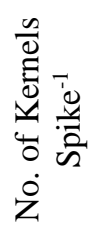 } & \multirow{2}{*}{1} & Clay & $-16.94 * *$ & $-12.76^{*}$ & $62.33 * *$ & $-2.79 * *$ & $11.84 * *$ & 0.1 & 5.57 & $-4.23 * *$ & $-13.69 * *$ \\
\hline & & Sandy & $-18.91 * *$ & $-16.88 * *$ & $61.62 * *$ & $-3.62 * *$ & $13.66 * *$ & 0.87 & 2.72 & $-4.73 * *$ & $-15.95 * *$ \\
\hline & \multirow{2}{*}{2} & Clay & $-30.89 * *$ & $21.28 * *$ & $57.44 * *$ & $2.22 * *$ & $-10.4 * *$ & $-14.9 * *$ & $69.57 * *$ & $-7.72 * *$ & -1.73 \\
\hline & & Sandy & $-28.35 * *$ & $7.18 *$ & $57.15^{* *}$ & $3.68 * *$ & 0.73 & -2.15 & $47.39 * *$ & $-7.08 * *$ & $-7.88 * *$ \\
\hline \multirow{4}{*}{ 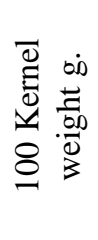 } & \multirow{2}{*}{1} & Clay & $-3.19 * *$ & $-1.40 * *$ & $4.57 * *$ & $0.18^{* *}$ & $0.80 * *$ & $0.77 * *$ & $2.39 * *$ & $-0.80 * *$ & $-1.70 * *$ \\
\hline & & Sandy & $-3.90 * *$ & $-1.84 * *$ & $3.93 * *$ & $-0.30 * *$ & $1.05^{* *}$ & -0.03 & $2.75 * *$ & $-0.97 * *$ & $-2.13^{* *}$ \\
\hline & \multirow{2}{*}{2} & Clay & $-1.83^{* *}$ & $-0.60 *$ & $4.43^{* *}$ & $0.18^{* *}$ & $0.38 *$ & 0.45 & $1.63 * *$ & $-0.45^{* *}$ & $-0.90 * *$ \\
\hline & & Sandy & $-1.72 * *$ & -0.31 & $3.97 * *$ & $0.23 * *$ & $0.36 *$ & 0.39 & $1.88 * *$ & $-0.43 * *$ & $-0.81 * *$ \\
\hline \multirow{4}{*}{ 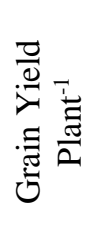 } & \multirow{2}{*}{1} & Clay & $-94.21 * *$ & $-43.61 * *$ & $24.71 * *$ & $2.18 * *$ & $14.6 * *$ & $17.73 * *$ & $67.46^{* *}$ & $-23.55^{* *}$ & $-45.96 * *$ \\
\hline & & Sandy & $-77.07 * *$ & $-35.84 * *$ & $20.33 * *$ & $-2.04 * *$ & $16.68 * *$ & $6.97 *$ & $54.97 * *$ & $-19.27 * *$ & $-40.00 * *$ \\
\hline & \multirow{2}{*}{2} & Clay & $-77.27 * *$ & $-27.12 * *$ & $28.07 * *$ & $4.05 * *$ & $19.58 * *$ & $13.29 * *$ & $66.87 * *$ & $-19.32 * *$ & $-40.07 * *$ \\
\hline & & Sandy & $-55.88 * *$ & $-24.02 * *$ & $20.61 * *$ & $4.24 * *$ & $16.1 * *$ & $15.18 * *$ & $42.48 * *$ & $-13.97 * *$ & $-30.68 * *$ \\
\hline
\end{tabular}

$*, * *$ Significant and highly significant at 0.05 and 0.01 respectively. 


\section{Scientific Journal of Agricultural Sciences 3 (1): 0-0, 2021}

explain the type of gene action controlling the trait in these crosses. The getting results are similar to those obtained by Gebrel et al. (2020), Aglan et al. (2020), Yassin and Ghareeb (2019), Abd El-Hamid and Ghareeb (2018), Al-Bakry et al. (2017) and Koumber and El-Gammaal (2012). The simple additive-dominance model was fit to interpret the genetic control for plant height in second hybrid under clay soil.

However, other remaining traits/crosses revealed the complexity effects and hence the analysis was further elongated to a digenic interaction.

\subsection{Gene effects}

The five parameters were used to estimate the nature of gene action (Table 5). The determined $F_{2}$ mean effects $(\mathrm{m})$ were found to be highly significant for all characters under the study in the two crosses and locations, indicating the ability to enhance the performance of these characters by pedigree selection.

The additive gene effects, (d) were found to be highly significantly positive and negative for all characters under study in two locations. These findings showed that the genetic materials that used in this research have decreasing allele expressions. The present findings were greatly agreed with those obtained by Abdel El-Aty ,M.S.,and y.S.Katta (2007), ElAwady (2011), Hammad (2014), Al-Bakry et al. (2017), Abd El-Hamid and Ghareeb. (2018) and Shehab-Eldeen et al. (2020). .

Concerning to the dominance gene effects (h), were significantly positive for no. of kernels spike ${ }^{-1}$, 100-kernel weight and grain yield Plant $^{-1}$ with the first cross in two location, No. of spike plant ${ }^{-1}$ in clay soil location and plant high in sandy soil. Whilst, significantly positive for No. of spike plant $^{-1}, 100$ kernel weight and grain yield plant ${ }^{-1}$ with the second cross in two location, plant height in clay soil location. These results indicated that dominance gene effects were involved in the heredity of these characters. Meanwhile, the negative values of (h) were observed for plant height, with second cross in sandy soil location. These findings reported that the alleles responsible for less value of these characters were dominant over the alleles contributing high values. These findings are in general agreement with those obtained by Abd El-Rahman (2013), Hammad (2014), Al-Bakry et al. (2017) and Abd El-Hamid and Ghareeb. (2018).

With respect to dominance $\mathrm{x}$ dominance (l) type of gene action was significant and positive for 100kernel weight, no. of spikes plant ${ }^{-1}$ and grain yield Plant $^{-1}$ with the two crosses in the two locations, no. of kernels spike ${ }^{-1}$ in second cross under the two locations and plant height in second cross under sandy soil location. Meanwhile, additive $\times$ additive type of gene effects(i), were significant with positive values for grain yield Plant ${ }^{-1}$ in the two crosses under the two locations and 100-kernel weight, in the first crosses under clay soil location, while, no. of spikes plant ${ }^{-1}$ was positive significant in first cross under clay soil location. So, selection in early segregating generations in wheat breeding program might be effective for these traits. However, significant negative values were detected for no. of spikes plant ${ }^{-1}$ in first cross under sandy soil location and no. of kernels spike $^{-1}$ with second cross in clay soil. These results makes selection to improve them in the early generations could not be successful. These findings are in agree with those previously obtained by Hammad (2014), Al-Bakry et al. (2017), Zaazaa (2017) and Abd ElHamid and Ghareeb. (2018).

Significant positive $F_{2}$ deviations $\left(E_{1}\right)$ were detected for plant height with cross number 1 under the two locations. In the meantime, $\left(\mathrm{E}_{1}\right)$ was found to be significant and negative for all characters under study except plant height. This may indicate that epistatic gene effects played a major role in the heredity of such characters. Moreover, insignificant $F_{2}$ deviation $\left(\mathrm{E}_{1}\right)$ was observed for plant height in second cross under the two locations. Which, indicates that the effect of epistatic genes have a minor role in the heredity of such trait. Similar trend was obtained earlier by Koumber and ElGammaal (2012). $F_{3}$ deviation values $\left(E_{2}\right)$ were significantly positive for plant height with first cross in the two locations and second cross in sandy soil location, but, was negative and significant with the second cross in clay soil location. Otherwise, significant and negative $\left(E_{2}\right)$ values were reported for $100-$ kernel weight, no. of spikes plant ${ }^{-1}$, no. of kernels spike ${ }^{-1}$ and grain yield Plant $^{-1}$ with the two crosses in the two locations. These findings would demonstrate the presence of epistasis gene effects to such an extent that a breeding program requires a great deal of attention. These results agree with those previously reported by Koumber and ElGammaal (2012) and Sharshar et al. (2020).

\subsection{Heterosis}

Cross combinations mean of different bread wheat characters were tested for the relatively expression to mid-parent heterosis (MP) or best-parent or heterobeltiosis (BP) were shown in Table (6). Results revealed that the desired significant and highly significant positive heterotic effects to mid-parents for two crosses in two location. These results are in 
conformity with the findings of Beche et al., (2013) for number of kernels per spike, Gebrel et al. (2020), Aglan et al. (2020), Yassin and Ghareeb (2019), Abd El-Hamid and Ghareeb. (2018) and Zaazaa et al. (2012) for most traits.

With respect to heterosis over the better parent, significantly positive values were detected for plant height with first cross under sandy soil location. Also, no. of spikes plant ${ }^{-1}$ with two crosses in sandy soil location only. These findings showed that the trend of dominance was across the best respective parent. The significant heterotic effect might be due to the dominance and/or dominance $\times$ dominance effects, confirming the previous results. These findings in general agree with Zaazaa et al. (2012), Abd ElRahman (2013) and Abd El-Hamid and Ghareeb. (2018). The feasibility of growing hybrid wheat cultivars mainly depends on the significant superiority of yield as well as the other contributing characters compared to the current commercial cultivars (Mahrous, 1998). Thus, heterosis over better parent may be useful in identifying the best hybrid combinations (Prasad et al. 1988).

\subsection{Inbreeding depression}

Concerning inbreeding depression percentage (ID $\%$ ), measured as relatively reduction in $\mathrm{F}_{2}$ 's mean compared to $F_{1}$ 's one (Table 6), positively highly significant values were attained for all characters under study, except plant height in first cross at clay and sandy soil locations. These results agree with those previously reported by Zaazaa (2017) and Abd El-Hamid and Ghareeb. (2018).

Table 6. Heterosis, potance ratio, and inbreading depression (I.D) of the mean for the studied characters in the two crosses and locations.

\begin{tabular}{|c|c|c|c|c|c|c|}
\hline \multirow{2}{*}{ Trait } & \multirow{2}{*}{ Cross } & \multirow{2}{*}{ Location } & \multicolumn{2}{|c|}{ Heterosis } & \multirow{2}{*}{ I.D } & \multirow{2}{*}{ P.ratic } \\
\hline & & & mid-par & b-par & & \\
\hline \multirow{4}{*}{ Plant High $\mathrm{cm}$. } & \multirow{2}{*}{1} & Clay & $13.83 * *$ & 6.14 & -0.49 & 1.91 \\
\hline & & Sandy & $16.18 * *$ & $10.98 *$ & 0.44 & 3.45 \\
\hline & \multirow{2}{*}{2} & Clay & $8.81 * *$ & 4.918 & $5.60 * *$ & 2.38 \\
\hline & & Sandy & $9.52 * *$ & 3.94 & $5.44 * *$ & 1.77 \\
\hline \multirow{4}{*}{ No.of Spike Plant ${ }^{-1}$} & \multirow{2}{*}{1} & Clay & $17.31 * *$ & 9.31 & $27.23 * *$ & 2.36 \\
\hline & & Sandy & $27.26 * *$ & $14.64 * *$ & $33.14 * *$ & 2.48 \\
\hline & \multirow{2}{*}{2} & Clay & $10.57 * *$ & 1.06 & $41.33 * *$ & 1.12 \\
\hline & & Sandy & $24.72 * *$ & $9.07 * *$ & $42.73 * *$ & 1.72 \\
\hline \multirow{4}{*}{ No. of Kernels Spike ${ }^{-1}$} & \multirow{2}{*}{1} & Clay & $9.69 * *$ & 5.08 & $10.49 * *$ & 2.21 \\
\hline & & Sandy & $8.75^{* *}$ & 2.89 & $10.86^{* *}$ & 1.54 \\
\hline & \multirow{2}{*}{2} & Clay & $15.36 * *$ & 11.82 & $17.72 * *$ & 4.19 \\
\hline & & Sandy & $14.67 * *$ & 8.03 & $16.72 * *$ & 2.38 \\
\hline \multirow{4}{*}{100 Kernels weight g. } & \multirow{2}{*}{1} & Clay & $7.73 * *$ & 4.03 & $17.93 * *$ & 2.17 \\
\hline & & Sandy & $10.08 * *$ & 3.41 & $23.54 * *$ & 1.56 \\
\hline & \multirow{2}{*}{2} & Clay & $5.89 * *$ & 2.09 & $11.86^{* *}$ & 1.58 \\
\hline & & Sandy & $10.49 *$ & 4.66 & $14.06^{* *}$ & 1.88 \\
\hline \multirow{4}{*}{ Grain Yield Plant ${ }^{-1}$} & \multirow[t]{2}{*}{1} & Clay & $2.57 *$ & -1.91 & $49.44 * *$ & 0.56 \\
\hline & & Sandy & $15.32 * *$ & 9.27 & $52.07 * *$ & 2.77 \\
\hline & \multirow{2}{*}{2} & Clay & $35.78 * *$ & $23.36 * *$ & $48.57 * *$ & 3.55 \\
\hline & & Sandy & $31.44 * *$ & $15.12 *$ & $47.53 * *$ & 2.22 \\
\hline
\end{tabular}

$*, * *$ Significant and highly significant at 0.05 and 0.01 respectively.

\subsection{Potance ratio}

With respect to the potence ratio, Table (6) presented that over-dominance effect (which their ratios were larger than unity) for all traits except grain yield plant $^{-1}$ with the first cross in clay soil location were recording ratios lower than unity, referring to partial dominance effect. Similar results were reported by Hendawy (2003), Koumber and El-Gammaal (2012) and Shehab-Eldeen et al. (2020). 


\section{Scientific Journal of Agricultural Sciences 3 (1): 101-110, 2021}

\subsection{Heritability and genetic advance}

Assessment of heritability of various traits is evidence of a plant breeder predicting the action of successive generations and helping to estimate the response to selection among generations. The heritability values in broad sense were high and ranged from 47.31 to $94.21 \%$ for all characters in all studied crosses revealing that most of the phenotypic variability was due to genetic effects (Table 7). The heritability values in narrow sense were high and ranged from 22.77 to $81.97 \%$ for all characters in all studied crosses, heritability in narrow-sense results were similar to these obtained by Farshadfar et al. (2013) for plant height and Khattab et al. (2010) for number of spikes plant ${ }^{-1}$ and grain yield plant- 1 .

Generally, heritability estimates presented a highly, moderate to low narrow-sense heritability for most cases. Results showed the considerable differences between broad and narrow-sense heritability in all crosses, suggesting the responsibility of the dominance gene action for the inheritance of most traits in the studied crosses and delayed selection may be more effective for improving characters of these genotypes.

Table 7. Broad and narrow- sense heritability and genetic advance in the two crosses.

\begin{tabular}{|c|c|c|c|c|c|c|}
\hline \multirow{2}{*}{ Traits } & \multirow{2}{*}{ Cross } & \multirow{2}{*}{ Location } & \multicolumn{2}{|c|}{ Heritability } & \multicolumn{2}{|c|}{ Genetic advance } \\
\hline & & & $\mathrm{H}(\mathrm{b} . \mathrm{s})$ & $\mathrm{H}(\mathrm{n} . \mathrm{s})$ & $\Delta \mathrm{g}$ & $\Delta \mathrm{g} \%$ \\
\hline \multirow{4}{*}{ Plant High $\mathrm{cm}$. } & \multirow{2}{*}{1} & Clay & 94.21 & 75.62 & 32.83 & 28.37 \\
\hline & & Sandy & 92.00 & 81.97 & 33.23 & 30.48 \\
\hline & \multirow{2}{*}{2} & Clay & 93.42 & 27.38 & 9.11 & 8.22 \\
\hline & & Sandy & 88.88 & 53.00 & 16.76 & 16.80 \\
\hline \multirow{4}{*}{ No.of Spike Plant ${ }^{-1}$} & \multirow{2}{*}{1} & Clay & 47.31 & 42.39 & 6.19 & 29.78 \\
\hline & & Sandy & 56.77 & 30.80 & 3.53 & 23.18 \\
\hline & \multirow{2}{*}{2} & Clay & 64.50 & 61.20 & 9.57 & 75.47 \\
\hline & & Sandy & 62.90 & 28.71 & 4.05 & 35.48 \\
\hline \multirow{4}{*}{ No. of Kernels Spike ${ }^{-1}$} & \multirow{2}{*}{1} & Clay & 73.73 & 33.81 & 12.41 & 19.91 \\
\hline & & Sandy & 73.04 & 28.67 & 10.17 & 16.50 \\
\hline & \multirow{2}{*}{2} & Clay & 75.95 & 42.23 & 11.63 & 20.25 \\
\hline & & Sandy & 60.12 & 25.32 & 6.62 & 11.59 \\
\hline \multirow{4}{*}{100 Kernels weight g. } & \multirow{2}{*}{1} & Clay & 62.46 & 24.27 & 0.45 & 9.79 \\
\hline & & Sandy & 55.59 & 22.77 & 0.37 & 9.38 \\
\hline & \multirow{2}{*}{2} & Clay & 62.05 & 35.04 & 0.63 & 14.16 \\
\hline & & Sandy & 48.05 & 29.27 & 0.45 & 11.29 \\
\hline \multirow{4}{*}{ Grain Yield Plant ${ }^{-1}$} & \multirow[t]{2}{*}{1} & Clay & 81.75 & 46.56 & 12.89 & 52.18 \\
\hline & & Sandy & 80.00 & 44.53 & 11.84 & 58.27 \\
\hline & \multirow{2}{*}{2} & Clay & 64.76 & 48.55 & 13.39 & 47.72 \\
\hline & & Sandy & 67.88 & 55.74 & 14.66 & 71.16 \\
\hline
\end{tabular}

\subsection{Genetic advance}

The findings of the present study reported that the expected genetic gain $(\Delta \mathrm{g})$ ranged from 9.11 to 33.23 for plant height, 4.05 to 9.57 for no. of spikes plant $^{-1}, 6.62$ to 12.41 for no. of kernels spike ${ }^{-1}, 0.37$ to 0.63 for 100-kernel weight and from 11.84 to 14.66 for grain yield plant ${ }^{-1}$ (Table 7). The highest expected genetic gain was found to be correlated with high heritability in narrow sense estimated in all studied characters. This conclusion coincide with the findings of Manal (2009) who pointed out that, characters with predicted genetic improvement and high heritability could be basically considered or making selection for these characters were mainly affected by the major effects of additive gene action. Meanwhile, Dixit et al. (1970) noted that, high genetic gain is often not correlated with high heritability, but high genetic advance should be correlated with high heritability in order to allow efficient selection. Generally, the most biometrical parameters had high values for most of the studied characters. Therefore, it could be noted that such crosses are important to wheat breeding program for genetic yield advancement. 


\section{REFERENCES}

Abdel El-Aty MS, Katta YS (2007). Estimation of genetic parameters using five populations in three bread wheat crosses. Egypt J. Plant Breed. 11(2):627 639 .

Abd El-Hamid EAM, Ghareeb ZE (2018). Generation mean analysis for estimating some genetic parameters in four bread wheat crosses. The 7th Field Crops Conference. FCRI, Giza, Egypt.(2018) P. 1729.

Abd El-Rahman Magda E (2013). Estimation of some genetic parameters through generation mean analysis in three bread wheat crosses. Alex. J. Agric. Res. 58(3):183-195.

Aglan MA, Eman N, Mohamed M, Shahin A (2020). Selection for yield, rust resistance and quality traits in early generations of Giza 171 X Sids 12 cross of bread wheat. J. of Plant Production, Mansoura Univ., 11(3):259 - 266.

Al-Bakry MR, Al-Naggar I, Ghareeb ZE, Mohamed SGA (2017). Gene effects and interrelationships of spike traits in bread wheat. Egypt. J. Plant Breed., 21(1):85-98.

Al-Naggar AMM, Shabana R, Abd El- Aleem MM, El-Rashidy Z (2017). Mode of inheritance of low-N tolerance adaptive traits in wheat (Triticum astivum L.) under contrasting nitrogen environments. Span. J. Agri. Res., 15(2):1-11.

Allard RW (1999). Principles of Plant Breeding, 2nd edition, John Wiley and Sons, New York, USA. pp. 254.

Dixit PK, Sexena PO, Bhatia LK (1970). Estimation of genotypic variability of some quantitative characters in groundnut. Indian J. Agric. Sci., 40:197201.

El-Awady Wafaa A (2011). Analysis of yield and its components using five parameters for three bread wheat crosses. Egypt. J. Agric. Res., 89 (3):993-1003.

Faridi H, Faubion JM (1995). Wheat End-uses Around the World. American Association of Cereal Chemists. Stpuel, Minnesota, USA.

Farshadfar E, Rafiee F, Hasheminasab H (2013). Evaluation of genetic parameters of agronomic and morpho-physiological indicators of drought tolerance in bread wheat (Triticum aestivum L.) using diallel mating design. AJCS 7(2):268-275.

Fethi, B, Mohamed EG (2010). Epistasis and genotype by environment interaction of grain yield related traits in durum wheat. Plant Breeding and Crop Sci. 2 (2): 24-29.

Gebrel EMAH, Ramadan RA, Mahgoub EM, Mahmod AA, Sadk EMM (2014). Genetic analysis of grain yield attributes and protein content in bread wheat under different nitrogen fertilization levels. J. Plant Prod. Mansoura Univ., 5(8): 201-213.

Gebrel EMA, El-Hawary MNA, El-Masry MY (2020). Genetic behavior of some agronomic traits in three bread wheat crosses using five population model. J. of Plant Production, Mansoura Univ.,Vol 11 (5):413 - 418, 2020

Hammad SM (2014). Estimation of genetic parameters in three bread wheat crosses. Minufiya J. Agric. Res., 39 (2): 703-710.

Hendawy H (2003). Gentic architecture of yield and its components and some other agronomic traits in bread wheat. Menufiya J. of Agric. Res. 28 (1) : 7186.

Johanson HW, Robinson HF, Comstock RE (1955). Estimation of genetic and environmental variability in soybean. Agron. J.47:314-318.

Khan FU, Mohammad F (2016). Application of stress selection indiced for assessment of nitrogen tolerance in wheat (Triticum astivum L.). J. Animal and Plant Sci., 26(1):201-210.

Khattab SAM, Esmail RM, AL-Ansary AMF (2010). Genetical analysis of some quantitative traits in bread wheat (Triticum aestivum L.). New York Science Journal, 3(11) 152-157.

Koumber RM, El-Gammaal AA (2012). Inheritance and gene action for yield and its attributes in three bread wheat crosses (Triticum aestivum L.). World J. of Agric. Sci., 8 (2): 156-162.

Mahrous AM (1998). Estimates of heterosis and combining ability for some quantitative characters in bread wheat. Minufiya J. Agric. Res., 23 (4):929-947.

Manal HE (2009). Estimation of heritability and genetic advance of yield traits in wheat (Triticum aestivum L.) under drought condition. Int. J. Genetics Mol. Bio., 1:115-120.

Mather K (1973). Genetical Structure of Populations. Chapman and hall, London.

Mather K, Jinks JK (1982). Biometrical Genetics. Great Br. Univ. Press, $3^{\text {rd }}$ ed

Miller PA, Williams JC, Robinson HF, Comstock RE (1958). Estimates of genotypes and environmental variances in upland cotton and their implications in selection. Agron. J. 50:126-181.

Prasad KD, Fhaque M, Ganguli DK (1988). Heterosis studies for yield and its components in bread wheat (Triticum aesiivum L). Indian J. Genet., 58: 97100.

Sharshar AM, Genedy MS, Ghareeb ZE (2020). Effect of sowing dates on genetic behavior for some bread wheat genotypes using five parameters model. 


\section{Scientific Journal of Agricultural Sciences 3 (1): 101-110, 2021}

Annals of Agric. Sci., Moshtohor ISSN 1110-0419 Vol. 58(4) (2020), 931 - 940.

Shehab-Eldeen MT, Darwish MAH, Ghareeb ZE (2020). Gene effect estimation for yield-characters and inheritance of yellow rust resistance among generations in three bread wheat crosses. IJISET International Journal of Innovative Science, Engineering \& Technology, Vol. 7 Issue 12, Dec. 2020.
Yassin MMM, Ghareeb ZE (2019). Genetic behavior of some economic characters in three wheat crosses. Egypt. J. Plant Breed. 23(7):1511-1523.

Zaazaa EI (2017). Genetic analysis of yield and its components in some bread wheat crosses (Triticum aestivum L.) using five populations model. J. plant prod., Mansoura Univ., 8 (11): 1215-1220.

Zaazaa, EI, Hager MA, EI-Hashash EF (2012). Genetical analysis of some quantitative traits in wheat using six parameters genetic model. American Eurasian J. Agric. \& Environ. Sci., 12 (4):456-462.

\section{الملخص العربي}

\section{دراسات وراثية للمحصول وبعض الصفات ذات الصلة في هجينين من قمح الخبز باستخدام نموذج خمسة}
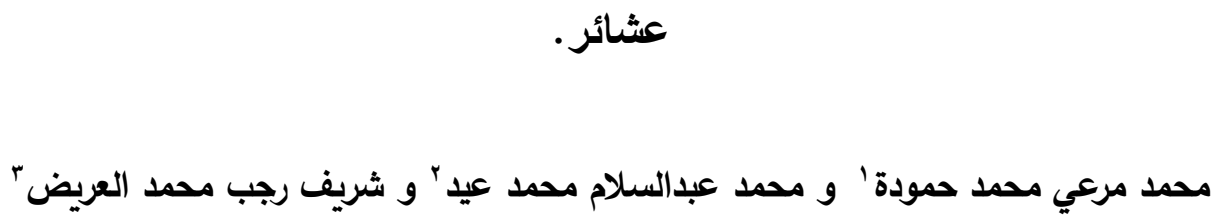

'قسم بحوث القدح - معهد بحوث المحاصيل الحقلية - مركز البحوث الزراعية - مصر ، بقسم المحاصيل - كلية الزراعة - جامعة الفيوم -

$$
\text { مصر ، "قسم المحاصيل - كلية الزراعة - جامعة بنى سويف - مصر . }
$$

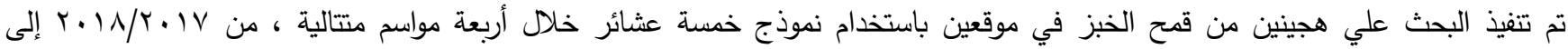

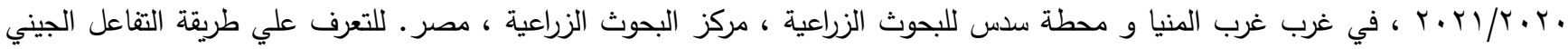

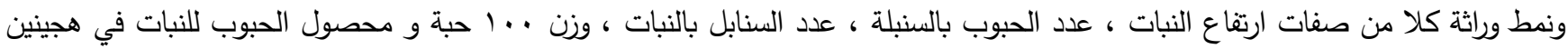

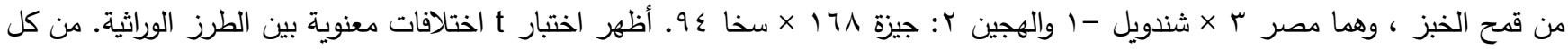

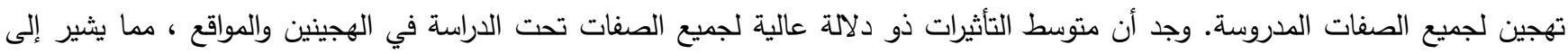
القدرة على تحسين أداء هذه الصفات عن طريق اختيار النسب. كثف scaling test عن وجود تفاعلات تفوقية في معظم الحالات المدروسة.

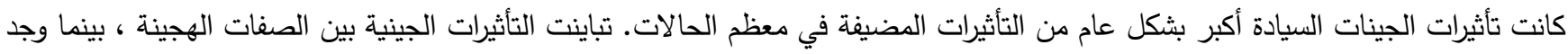

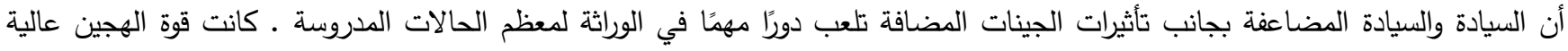
المعنوية في كلا من الهجين الاول والثاني في الموقعين تحت الدراسة ـ أظهرت تقديرات درجة التوريث بالمعنى الواسع قيمًا معتدلة في معظم الحالات. تم العثور على أعلى مكاسب جينية متوقعة مرتبطة بالوراثة العالية بالمعنى الضيق المقدّر في جميع الصفات المدروسة. 